\title{
Paragoge as an indicator of language contact
}

\author{
E-Ching Ng \\ e-ching.ng@yale.edu \\ Yale University
}

Word-final vowel epenthesis is robustly attested in all types of language contact, but vanishingly rare in "normal" L1 transmission. I propose that this sound change is associated with effortful speech, which is common in language contact but not in L1 transmission.

\section{Data}

Word-final vowel epenthesis (henceforth paragoge) is abundantly attested in second language (L2) acquisition (1), loanword adaptation (2) and creole phonology (3) across diverse language families.

(1) L2 acquisition (Tarone 1980)

English sack $\rightarrow$ L1 Korean interlanguage [sæk므]

English blanket $\rightarrow$ L1 Portuguese interlanguage [bænkว̊ํ]]

(2) Loanword adaptation (Uffman 2007; Haspelmath \& Tadmor 2009)

English class $>$ Yoruba [kíláàsi]

German Arbeit $>$ Japanese [arubaito]

Arabic nū $r>$ Swahili [nuru] 'light'

Malay burung > Malagasy [vorona] 'bird'

(3) Creolization ${ }^{1}$

English big > Sranan bigi (Wilner 2003: 124)

Eng. school > Sol. Isl. Pidgin sukulu (Jourdan \& Keesing 1997: 413)

Eng. walk > Kromanti waka (Bilby 1983: 42)

Portuguese doutor $>$ São Tome dotolo 'doctor' (Lipski 2000)

Dutch pompoen > Berbice D. Cr. pampuna 'pumpkin' (Singh \& Muysken 1995)

In contrast, paragoge is sometimes claimed to be unattested and even impossible as a synchronic process (Sanders 1979; Steriade 2001/2008). Similarly, paragoge is considered unattested or rare as a regular historical sound change (Campbell 1999: 35).

I have found that paragoge is in fact attested diachronically, but many cases coincide with well-known cases of language contact. Several South Dravidian languages have a paragogic vowel, possibly due to Prakrit influence (Kanapathi Pillai 1943). Paragoge in Sardinian, e.g. hic > ikke (Lüdtke 1988: 344-5), may be linked to repeated waves of colonization by both Carthage and Rome (Dyson \& Rowland 2007). Old Spanish may or may not have undergone sufficient Celtic influence to explain phrase-final $-e$ after sonorants in terms of language contact (Honsa 1962); a pattern which appears to have survived in New Mexico Spanish (Bills \& Vigil 2008: 15, 149). However, contact with African languages is certainly a plausible explanation for paragoge in early Brazilian Portuguese (Romance: Lipski 2000: 55). There is insufficient

\footnotetext{
${ }^{1}$ French creoles appear to lack paragoge categorically (Singh \& Muysken 1995). A possible account is given in $\mathrm{Ng}$ (2013).
}

evidence for or against contact as an explanation for paragoge in Anguthimri, an extinct Australian Pama-Nyungan language (Crowley 1981; Smith 1984). Interestingly, paragoge occurs repeatedly in Austronesian languages (Talaud, Sangir, Sangil, Bantik: Sneddon 1993; Lauje: Himmelmann 1997; Leti, Kambera: Blevins \& Garrett 1998: 542ff), especially in East Indonesia, where language contact has been so intense that language relationships are difficult to reconstruct. There is also independent evidence of typological similarities between some Southeast Asian languages and creoles (Bakker et al. 2011: fig. 34).

Rather than inserting a vowel, the usual repairs to a wordfinal consonant in L1 transmission are devoicing, deletion, and other changes affecting the consonant itself (cf. Bybee 2001: 206ff). These also occur in language contact. The typology can be summed up as follows:

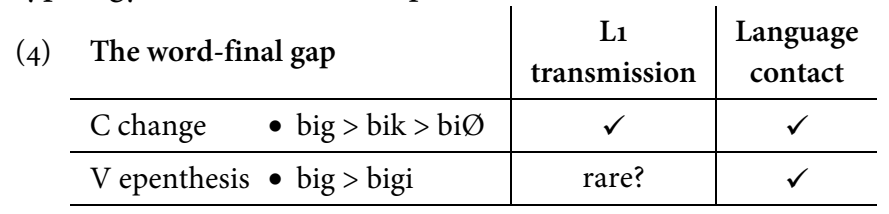

\section{Rejected accounts}

This study is not the first to suggest that paragoge can be used as a diagnostic of previous language contact (Singh \& Muysken 1995). However, previous explanations of its asymmetrical distribution are wanting.

Eckman (2004: 526) observed that paragoge occurs in L2 acquisition when there is a clash between an L1 surface constraint forbidding certain word-final consonants and L2 input containing such word-final consonants. He argued that such a conflict is impossible within L1, hence paragoge cannot occur in L1 phonology. This proposal satisfactorily restricts paragoge to the language contact situations where it is observed, but is problematic with respect to L1 phonology, because conflicts between surface constraints and underlying forms are now common in Optimality Theory analyses of voicing alternation in root-final obstruents (e.g. Dutch, German, Russian, Turkish).

Other relevant proposals exist, but are inconsistent with the data. (1) Young-Scholten, Akita and Cross (1999) suggest that written input blocks deletion in L2 acquisition, hence favouring paragoge as a means of creating CV syllables. However, this does not explain why paragoge also occurs in creolization, where written input is generally unavailable.

(2) Some loanword adaptation studies have argued that epenthesis is generally favoured over deletion as a means of 
creating CV syllables, in language contact or otherwise. One proposal is that deletion is dispreferred because it would destroy segmental contrasts (Paradis and LaCharité 1997). Another is that vowel epenthesis changes fewer features than consonant deletion (Uffman 2007: 206). These proposals are consistent with loanword adaptation data, but they do not explain the rarity of paragoge in L1 transmission. (3) Steriade (2001/2008) argues that final voiced obstruents will not be repaired by paragoge because devoicing produces the most perceptually similar result. But this does not explain why paragoge occurs so freely in language contact situations. Furthermore, paragoge was found to produce a closer perceptual match than devoicing in one study of English listeners (Kawahara and Garvey 2010).

I considered, but ultimately rejected an account based on asymmetries between child and adult learners. Like other types of epenthesis, paragoge is rare in child speech errors compared to deletion (Demuth et al. 2006). This may be because: (1) paragoge is blocked during the monosyllabic stage of early acquisition (Fikkert 1994); (2) children do not self-monitor their production as effectively as adults, hence deletion is not blocked (Jaeger 2005: 82); (3) children may find codas easier to produce than onsets for at least some consonant types (McAllister 2009). It is tempting to draw a parallel between the typology of child acquisition and sound change in this respect, but it has been convincingly demonstrated that common child errors such as the hardening of fricatives to stops, consonant harmony affecting major place of articulation, and stressed syllable deletion do not occur as sound changes (Foulkes \& Vihman, in press). As these errors tend to disappear by the age of five, it is perhaps unsurprising that they are not propagated in the wider speech community. Since there are no sound changes with demonstrable origins in child phonology, it would be problematic to trace the absence of a sound change to a gap in child phonology.

\section{My proposal}

I propose that paragoge is blocked in L1 transmission because its phonetic antecedents are rare in casual speech, which forms the majority of speech experience in L1 transmission. Casual speech is defined in Articulatory Phonology as "that fluent subset of fast speech in which reductions typically occur" (Browman \& Goldstein 1991: 323). It is associated with the reduction and increased overlap of articulatory gestures, both processes which follow from a faster speech rate. Gestural reduction (e.g. $d>ð$ ) may occur when there is insufficient time to fully achieve the targeted constriction of the oral tract. "Crowding" more gestures into a shorter span of time also causes greater overlap between gestures, which may result in assimilation (e.g. come from $[\mathrm{k} \Lambda \mathrm{m}$ frəm]), deletion (e.g. perfect memory) and even consonant epenthesis (Chompsky).
In this way, casual speech provides phonetic antecedents for a great many sound changes (Bybee 2001: 69ff, 199ff). Gestural reduction and overlap are transparently related to lenition and coarticulation, two out of three of the "primary articulatory transforms" that Blevins (2004) identifies in shaping sound change. Only the third category, fortition, cannot be related to gestural reduction or overlap.

Both deletion and devoicing, the two most common wordfinal consonant repairs in L1 transmission, can be traced to gestural reduction or overlap. Deletion is uncontroversially linked to gestural reduction or overlap as aforementioned. Word-final devoicing, however, is often seen as fortition, because word-medial voicing clearly participates in lenition chains (Lavoie 2001), and because final devoicing can be accompanied by aspirated release bursts (Iverson \& Salmons 2011). But if we examine the articulatory antecedents of wordfinal devoicing, it resembles lenition more than fortition. Voicing requires a difference in air pressure above and below the larynx, but over the course of an utterance the pressure is gradually equalized, such that it becomes especially aerodynamically difficult to sustain voicing domain-finally (Ohala 1983; Blevins 2004: 195). Laryngeal gestures are still an ongoing area of research in Articulatory Phonology, but I would argue that because final devoicing emerges when the largyneal target of voicing is not fully maintained, devoicing in this context should be seen as a form of gestural reduction. ${ }^{2}$ In this way, both of the most common word-final consonant repairs in L1 transmission can be linked to casual speech production.

I suggest that all sound changes originating in articulatory variation (as opposed to perception or language contact) should be traced to casual speech. Sound changes classed as fortition, such as consonant hardening and vowel diphthongization, are apparent counter-examples because they cannot be linked to gestural reduction or overlap. However, fortition usually coincides with domain-initial or stressed positions (Lavoie 2001), precisely where articulatory gestures are lengthened, strengthened and less overlapped (refs. in Katsika 2012: ch. 2). ${ }^{3}$ Fortition in these prosodically strong positions is therefore also consistent with casual speech production.

Unlike sound changes common in L1 transmission, paragoge lacks phonetic antecedents in casual speech production. Blevins (2004: 155) has proposed that an important source of vowel epenthesis is the reinterpretation

\footnotetext{
${ }^{2}$ Alternatively, word-final devoicing can be seen as gestural overlap between a laryngeal voicing gesture and a return to a neutral laryngeal posture domain-finally.

${ }^{3}$ Some studies find similar phonetic effects domain-finally, but these appear to be phonologized only rarely. Future work is needed to determine why.
} 
of obstruent release bursts as $\mathrm{CV}$ sequences. ${ }^{4}$ This is consistent with studies of $\mathrm{L}_{2}$ epenthesis, which indicate that L2 speakers do not insert a targeted vowel gesture into an unfamiliar sequence of consonants, but rather "pull apart" or separate the consonant gestures (Davidson 2007). This "pulled apart" timing can emerge in L2 production even when it is not found in learners' L1 (Zsiga 2003). ${ }^{5}$ The resulting transition between consonant gestures is often perceived as an epenthetic vowel.

If these findings are representative, then paragoge is characteristically found in L2 speech due to reduced gestural overlap, the opposite of what happens in casual speech. I will refer to this as effortful speech, because L2 learners actually produce more epenthesis for minimal pairs than read sentences or conversation tasks (Lin 2001). In this restrictive sense of effort, paragoge can be seen as one type of fortition (cf. Blevins 2004: 146). Its rarity as a sound change then follows from the fact that fortition can be situated in casual speech production only in prosodically strong positions. Paragoge, in contrast, is word-final by definition, a position which is usually seen as phonetically and phonologically weak (e.g. Harris 2009).

It is likely that effortful speech is not equally common in L1 transmission and language contact. Since L2 speakers have far less articulatory experience to draw on, it follows that their speech might not be as fast or fluent as casual speech. Some L2 speakers may be fluent enough to produce casual speech, but in many language contact situations, such as loanword adaptation or creolization, there would also be enough nonfluent speakers and effortful speech to influence the emerging phonology (cf. LaCharité \& Paradis 2005; Singler 2008). This is consistent with the presence of sound changes associated with both casual and effortful speech in language contact (4). In L1 transmission, on the other hand, the majority of speech experience comes from fluent speakers, such that casual speech should predominate. ${ }^{6}$ I propose that typical L1 transmission does not include enough effortful speech experience for paragoge and other types of fortition to be phonologized along this path of change.

${ }^{4}$ Blevins (2004: 155) suggests that another source of vowel epenthesis is reinterpretation of syllabic sonorants as CV sequences. This may be the origin of Old Spanish paragoge.

${ }^{5}$ Zsiga (2003) found that L2 speakers reduced gestural overlap word-medially as well as across word boundaries. This suggests that word-medial vowel epenthesis, like paragoge, should be much more common in language contact than in L1 transmission.

${ }^{6}$ Dialect contact as observed in hypercorrection is a special case. Non-native dialect speakers might produce effortful speech due to unfamiliarity with the necessary articulations. Because articulatory unfamiliarity is the crucial point in this account, dialect contact counts as a special case of language contact rather than $\mathrm{L}_{1}$ transmission for the purposes of this study.
There are potentially other paths of change which could lead to paragoge. These include rule inversion (reinterpretation of a deletion process as epenthesis, e.g. French e muet), morphological accretion (when prosodically weak material is incorporated into a preceding word), or sporadic change in words which are hyperarticulated (e.g. Italian letter names elle, emme, effe: Lüdtke 1988: 345). None of these involve effortful speech.

One prediction of this proposal is that $\mathrm{L} 1$ transmission should lack not only paragoge, but also other types of wordfinal fortition originating in effortful speech. An apparent counter-example is word-final obstruent epenthesis after high vowels, which occurs across diverse language families in situations that are unlikely to involve heavy language contact (Mortensen 2012); Joseph Salmons, p.c. 27 Jan 2013. But the proposed path of change relies on domain-final devoicing, which I have argued is more articulatorily akin to lenition than fortition. A similar path of change may be responsible for word-final hardening of fricatives to stops in Korean (s, s', $\mathrm{h}>\mathrm{t}$ ), a subset of coronal neutralization (Kim \& Jongman 1996; Ilkyu Kim, p.c. 16 Jan 2013). Crucially, neither of these types of fortition are reported to be common in language contact, indicating that their origins are different from paragoge.

A number of questions about the relationship between articulatory phonetics and sound change remain unanswered. For instance, it remains surprising that word-final fortition is rare in L1 transmission, because articulatory gestures are reported to be lengthened, strengthened and less overlapped domain-finally as well as initially, although this effect may be limited to higher prosodic domains than the word (Keating, Wright and Zhang 2001). However, I hope this study shows that cross-fertilization between the fields of phonetics, historical linguistics and language contact can be fruitful, and paves the way for future work.

\section{References}

Bakker, Peter, Aymeric Daval-Markussen, Mikael Parkvall, \& Ingo Plag (2011). Creoles are typologically distinct from non-creoles. Journal of Pidgin and Creole Languages 26(1): 5-42.

Bilby, Kenneth M. (1983). How the "older heads" talk: A Jamaican Maroon spirit possession language and its relationship to the creoles of Suriname and Sierra Leone. Nieuwe West-Indische Gids [New West Indian Guide] 57: 37-88.

Bills, Garland D. \& Neddy A. Vigil (2008). The Spanish language of New Mexico and southern Colorado: A linguistic atlas. Albuquerque: University of New Mexico.

Blevins, Juliette (2004). Evolutionary phonology: The emergence of sound patterns. Cambridge, UK: Cambridge University Press.

Blevins, Juliette \& Andrew Garrett (1998). The origins of consonant-vowel metathesis. Language 74(3): 508-556.

Browman, Catherine \& Louis Goldstein (1991). Gestural structures: Distinctiveness, phonological processes, and historical change. In Modularity and the motor theory of speech perception, ed. by Ignatius G. 
Mattingly \& Michael Studdert-Kennedy. Hillsdale, NJ: Lawrence Erlbaum Associates. 313-338.

Bybee, Joan L. (2001). Phonology and Language Use. Cambridge, UK: Cambridge University Press.

Campbell, Lyle (1999). Historical linguistics: An introduction. Cambridge, MA: MIT Press.

Crowley, Terry (1981). The Mpakwithi dialect of Anguthimri. In Handbook of Australian languages, Volume 2, ed. by R. M. W. Dixon \& Barry J. Blake. Canberra: Australian National University Press. 146-194.

Davidson, Lisa (2007). The relationship between the perception of non-native phonotactics and loanword adaptation. Phonology 24: 261-286.

Demuth, Katherine, Jennifer Culbertson, \& Jennifer Alter (2006). Wordminimality, epenthesis and coda licensing in the early acquisition of English. Language and Speech 49(2): 137-174.

Dyson, Stephen L. \& Junior Rowland, Robert J. (2007). Archaeology and history in Sardinia from the Stone Age to the Middle Ages: Shepherds, sailors, \& conquerors. Philadelphia, PA: University of Pennsylvania Museum of Archaeology and Anthropology.

Eckman, Fred R. (2004). From phonemic differences to constraint rankings: Research on second language phonology. Studies in Second Language Acquisition 26(4): 513-549.

Fikkert, Paula (1994). On the acquisition of prosodic structure. The Hague: Holland Institute of Generative Linguistics.

Foulkes, Paul \& Marilyn. M. Vihman (in press). Language acquisition and phonological change. In The Handbook of Historical Phonology, ed. by P. Honeybone \& J. C. Salmons. Oxford: Oxford University Press.

Harris, John (2009). Why final obstruent devoicing is weakening. In Strength relations in phonology, ed. by Kuniya Nasakuwa \& Phillip Backley. Berlin; New York: Mouton de Gruyter. 9-45.

Haspelmath, Martin \& Uri Tadmor, eds. (2009). World Loanword Database. Munich: Max Planck Digital Library. Accessed 24 Nov 2012: http://wold.livingsources.org/vocabulary/1.

Himmelmann, Nikolaus P. (1997). The paragogic vowel in Lauje (TominiTolitoli): Phonology or morphosyntax? In Proceedings of the Seventh International Conference on Austronesian Linguistics, Leiden, 22-27 August 1994, ed. by Cecilia Odé \& Wim Stokhof. Amsterdam; Atlanta, GA: Rodopi. 81-103.

Honsa, Vladimír (1962). Old Spanish paragogic -e. Hispania 45(2): 242-246.

Iverson, Gregory K. \& Joseph C. Salmons (2011). Final devoicing and final laryngeal neutralization. In The Blackwell Companion to Phonology, Volume III: Phonological Processes, ed. by Marc van Oostendorp, Colin J. Ewen, \& Keren Rice. Malden, MA; Oxford: Wiley-Blackwell. 1622-1643.

Jaeger, Jeri J. (2005). Kids' slips: what young children's slips of the tongue reveal about language development. Mahwah, NJ: Lawrence Erlbaum.

Jourdan, Christine \& Roger Keesing (1997). From Fisin to Pijin: Creolization in process in the Solomon Islands. Language in Society 26: 401-420.

Kanapathi Pillai, K. (1943). The enunciative vowel in Dravidian. University of Ceylon Review : $35-41$.

Katsika, Argyro (2012). Coordination of prosodic gestures at boundaries in Greek. Ph.D. dissertation, Yale University.

Kawahara, Shigeto \& Kelly Garvey (2010). Testing the P-map hypothesis: Coda devoicing. Rutgers Optimality Archive 1087.

Keating, Patricia, Richard Wright \& Jie Zhang (2001). Word-level asymmetries in consonant articulation. Ms., UCLA.

Kim, Hyunsoon \& Allard Jongman (1996). Acoustic and perceptual evidence for complete neutralization of manner of articulation in Korean. Journal of Phonetics 24(3): 295-312.

LaCharité, Darlene \& Carole Paradis (2005). Category preservation and proximity versus phonetic approximation in loanword adaptation. Linguistic Inquiry 36(2): 223-258.

Lavoie, Lisa M. (2001). Consonant strength: Phonological patterns and phonetic manifestations. New York; London: Garland.
Lin, Yuh-Huey (2001). Syllable simplification strategies: A stylistic perspective. Language Learning 51(4): 681-718.

Lipski, John M. (200o). Epenthesis vs. elision in Afro-Iberian language: A constraint-based approach to creole phonology. Papia 10: 23-39.

Lüdtke, Helmut (1988). The importance of dialectology for a new look at Romance linguistic history. In Historical dialectology: Regional and social, ed. by Jacek Fisiak. Berlin; New York: Mouton de Gruyter. 337347.

McAllister, Tara (2009). The articulatory basis of positional asymmetries in phonological acquisition. Ph.D. dissertation, MIT.

Mortensen, David R. (2012). The emergence of obstruents after high vowels. Diachronica 29(4): 434-470.

Ng, E-Ching (2013). When contact doesn't favor paragoge. Paper presented at the Society for Pidgin and Creole Linguistics, Boston, 4-5 Jan.

Ohala, John J. (1983). The origin of sound patterns in vocal tract constraints. In The production of speech, ed. by Peter F. MacNeilage. New York: Springer-Verlag. 189-216.

Paradis, Carole \& Darlene LaCharité (1997). Preservation and minimality in loanword adaptation. Journal of Linguistics 33 (2): 379-430.

Plag, Ingo \& Christian Uffmann (2000). Phonological restructuring in creole: The development of paragoge in Sranan. In Degrees of restructuring in creole languages, ed. by Edgar Werner Schneider. Amsterdam; Philadelphia, PA: John Benjamins. 309-336.

Sanders, Gerald (1979). Equational rules and rule function in phonology. In Current approaches in phonological theory, ed. by D. Dinnsen. Bloomington, IN: Indiana University Press, 74-105.

Singh, Rajendra \& Pieter Muysken (1995). Wanted: A debate in pidgin/creole phonology. Journal of Pidgin and Creole Languages 10(1): 157-169.

Singler, John Victor (2008). The sociohistorical context of creole genesis. In The Handbook of Pidgin and Creole Studies, ed. by Silvia Kouwenberg \& John Victor Singler. Chichester; Malden, MA: Blackwell. 332-358.

Smith, Norval S. H. (1984). All change on the CV-tier: Developments in the history of Awntim and Anutimri. In Linguistics in the Netherlands 1984, ed. by H. Bennis \& W. U. S. v. L. Kloeke. Dordrecht: Foris. 169178.

Sneddon, James Neil (1993). The drift towards final open open syllables in Sulawesi languages. Oceanic Linguistics 32(1): 1-44.

Steriade, Donca (2001/2008). The phonology of perceptibility effects: The $\mathrm{p}$ map and its consequences for constraint organization. In The nature of the word, ed. by Kristin Hanson \& Sharon Inkelas. Cambridge, MA: MIT Press. 151-179. Originally circulated in 2001.

Tarone, Elaine (1980). Some influences on the syllable structure of interlanguage phonology. IRAL, International Review of Applied Linguistics in Language Teaching 18: 139-152.

Uffman, Christian (2007). Vowel epenthesis in loanword adaptation. Tübingen: Niemeyer.

Wilner, John, ed. (2003). Wortubuku ini Sranan Tongo (Sranan Tongo English dictionary). 4th edn. Paramaribo: Summer Institute of Linguistics.

Young-Scholten, M., M. Akita, \& N. Cross (1999). Focus on form in phonology: Orthographic exposure as a promoter of epenthesis. In Pragmatics and pedagogy, ed. by P. Robinson \& J. O. Jungheim. Tokyo: Aoyama Gakuin University. 64-101.

Zsiga, Elizabeth C. (2003). Articulatory timing in a second language: Evidence from Russian and English. Studies in Second Language Acquisition 25: 399-432. 